\title{
Produktivitas Kerja Dalam Perspektif Ekonomi Islam
}

\author{
Baharuddin \\ Pasca Sarjana Institut Agama Islam Negeri (IAIN) Parepare \\ Rialbapard15@gmail.com
}

\begin{abstract}
Abstrak
Sistem Ekonomi Islam tidak sekedar memandang kerja sebagai pendorong utama aktivitas perekonomian, tapi lebih dari itu kerja merupakan perbuatan mulia dalam rangka mewujudkan kemaslahatan individu dan masyarakat. Bekerja dalam sistem ekonomi Islam merupakan suatu keharusan sebagai kewajiban syara' dan dipandang sebagai bentuk ibadah bagi yang melakukannya. Sehingga segala bentuk pengangguran, termasuk memintaminta dipandang sebagai perbuatan tercela. Bekerja mendapat perhatian khusus baik dalam Al-Qur'an maupun Hadits-Hadist Nabi Muhammad SAW.
\end{abstract}

Kata Kunci: Kerja, Ekonomi, Hadis

\section{Pendahuluan}

Islam sebagai agama wahyu telah melahirkan suatu sistem ekonomi holistik yang dikenal dengan sistem ekonomi Islam. Selain agama Islam tidak ada agama lain di dunia yang melahirkan sistem ekonomi. Sistem- sistem ekonomi yang ada di dunia selain sistem ekonomi Islam tidak lahir dari agama tetapi lahir dari paham-paham tertentu. Seperti sistem ekonomi kapitalis lahir dari paham kapitalisme, sistem ekonomi komunis lahir dari paham komunisme, dan sistem ekonomi sosialis lahir dari paham sosialisme. Berbeda dengan bangunan sistem ekonomi lain yang materialistik, bangunan sistem ekonomi Islam meliputi aspek material dan spritual. Pandangan Sistem ekonomi Islam juga bukan hanya menjangkau dunia tapi juga akhirat yang tidak pernah tersentuh oleh sistem ekonomilain. Karena bangunan dan pandangan sistem ekonomi Islam komprehensip dan universal maka sistem ekonomi Islam adalah sistem ekonomi holistik.

Salah satu unsur penting ekonomi yang mendapat perhatian besar 
berbagai sistem ekonomi tidak terkecuali sistem ekonomi Islam adalah dunia kerja. Karena dapat dimaklumi bahwa kerja merupakan pendorong utama aktivitas perekonomian baik secara mikro maupun secara makro. Secara mikro kerja merupakan sarana bagi setiap manusia untuk dapat tetap bertahan hidup. Dimana dengan bekerja seseorang akan dapat memenuhi dan mencukupi kebutuhan hidupnya. Semangat dan kemampuan atau keterampilan kerja seseorang juga akan menentukan tingkat kesejahteraannya (hayyatan thayyibah). Disamping itu bekerja akan meneguhkan fitrah dan martabat kemanusiaannya dihadapan Allah. Dan lebih dari itu, dengan bekerja seseorang telah menjadi bagian dari siklus rezeki (sunnatullah), yaitu memberi nilai dan mafaat kepada sesama manusia (alturistik).

Pada tataran makro aktivitas kerja masyarakat menjadi bagian faktor produksi yang sangat menentukan agregat produktivitas yang menjadi ukuran tingkat pertumbuhan ekonomi suatu negara. Dengan demikian kemampuan kerja masyarakat dan produktivitasnya menjadi aspek penentu maju dan mundurnya suatu bangsa. Dalam hal ini negara mempunyai kewajiban untuk meningkatkan kemampuan kerja masyarakat dan menyediakan lapangan Kerja. Ketidakmampuan masyarakat dalam bekerja akan menimbulkan kemiskinan dan keterbatasan lapangan kerja juga akan menimbulkan pengangguran.

Oleh karena itu, sistem Ekonomi Islam tidak sekedar memandang kerja sebagai pendorong utama aktivitas perekonomian, tapi lebih dari itu kerja merupakan perbuatan mulia dalam rangka mewujudkan kemaslahatan bersama. Bekerja merupakan perintah Allah SWT dan menjadi sunnah Rosulullah SAW. Sehingga segala bentuk pengangguran, termasuk memintaminta merupakan perbuatan tercela. Dengan demikian bekerja dalam sistem ekonomi Islam merupakan suatu keharusan bagi setiap muslim sebagai kewajiban syara` dan dipandang sebagai bentuk ibadah bagi yang melakukannya. 


\section{Konsep Kerja Dan Produktivitas Dalam Islam}

Dalam agama Islam, tindakan atau sesuatu yang dikerjakan seseorang seringkali didefinisikan dengan istilah amalan. Amalan atau pekerjaan dalam Islam diarahkan untuk memenuhi kewajiban seseorang sebagai upaya untuk mendekatkan diri kepada Allah. Menurut Asyraf Hj Ab Rahman istilah "kerja” dalam Islam bukanlah semata-mata merujuk kepada mencari rezeki untuk menghidupi diri dan keluarga dengan menghabiskan waktu siang maupun malam, dari pagi hingga sore, terus menerus tak kenal lelah, tetapi mencakup segala bentuk amalan atau pekerjaan yang mempunyai unsur kebaikan dan keberkahan bagi diri, keluarga dan masyarakat sekelilingnya serta negara. ${ }^{1}$

Menurut Pramandhika sesorang yang bekerja adalah adalah mereka yang menyumbangkan jiwa dan tenaganya untuk kebaikan diri, keluarga, masyarakat, dan negara tanpa menyusahkan orang lain. Oleh karena itu, kategori "ahli surga” seperti yang digambarkan dalam al-Qur'an bukanlah orang yang mempunyai pekerjaan/jabatan yang tinggi dalam suatu organisasi, tetapi orang yang mempunyai derajat taqwa kepada Allah, yaitu orang yang khusyu dalam shalatnya, baik tutur katanya, memelihara kemaluannya serta menunaikan tanggungjawab sosialnya seperti mengeluarkan zakat dan lainnya.

Selain Al-Qur'an sebagai pedoman dalam hidup, hadits dalam Islam juga merupakan pedoman bagi manusia dalam bertindak atau melakukan suatu perbuatan, berikut merupakan beberapa Hadits yang menjelaskan pentingnya bekerja dalam Islam:

"Rasulullah SAW. pernah ditanya, pekerjaan apa yang paling baik? Beliau menjawab, pekerjaan terbaik adalah usaha yang seseorang dengan tangannya sendiri dan semua perjualbelian yang dianggap baik." (HR. Ahmad dan Baihaqi) ${ }^{2}$

\footnotetext{
${ }^{1}$ Muhammad Iqbal Noor, Motivasi Islam Dan Motivasi Prososial Pada Lembaga Amil Zakat (Semarang: Fak Ekonomi dan Bisnis, 2012), h. 41

2 Muhammad Iqbal Noor, Motivasi ...., h. 43
} 
Dalam hadits yang disebutkan diatas, menunjukan bahwa bekerja merupakan perbuatan yang sangat baik dan mulia dalam ajaran Islam. Bekerja bahkan dapat menjadikan seseorang dapat diampuni dosa-dosanya. Dan bagi orang yang bekerja dengan tangannya sendiri untuk memuhi kebutuhan hidupnya maupun kebutuhan anak dan isterinya, maka orang seperti ini dikategorikan sebagai jihad fi sabilillah. Dengan demikian bekerja dalam ajaran Islam merupakan sesuatu yang penting dan harus sesuai dengan apa yang telah disebutkan dalam Al-Qur'an dan Hadits.

Bekerja untuk mencari nafkah adalah hal yang istimewa dalam pandangan Islam. Allah telah berjanji kepada orang yang beriman dan melakukan pekerjaan yang baik bahwa bagi mereka ampunan Allah dan ganjaran yang besar. Ayat ini menunjukkan bahwa adanya motivasi kerja yang utuh dalam Islam. Motivasi bekerja untuk mendapatkan ampunan dan ganjaran Allah adalah motivasi terbesar bagi seorang muslim. Bekerja dalam Islam tidak hanya mengejar "bonus duniawi" namun juga sebagai amal soleh manusia untuk menuju kepada kekekalan. Allah SWT berfirman dalam QS. Adz-Dzariyat/51:22 disebutkan :

Terjemah:

"Dan di langit terdapat (sebab-sebab) rezkimu dan terdapat (pula) apa yang dijanjikan kepadamu". ${ }^{3}$

Allah SWT berfirman dalam QS. Hud/11:9 disebutkan :

Terjemah:

"Dan tidak ada suatu binatang melata pun di bumi melainkan Allah-lah yang memberi rezkinya, dan dia mengetahui tempat berdiam binatang itu dan tempat penyimpanannya semuanya tertulis dalam Kitab yang nyata (Lauh mahfuzh)".4

${ }^{3}$ Departemen Agama Republik Indonesia, Al-Qur'an dan Terjemahannya, h. 522

4 Departemen Agama Republik Indonesia, Al-Qur'an..., h. 223 
Allah SWT berfirman dalam QS. Al-Ankabut/29:60 disebutkan :

Terjemah:

"Dan berapa banyak binatang yang tidak (dapat) membawa (mengurus) rezkinya sendiri. Allah-lah yang memberi rezki kepadanya dan kepadamu dan dia Maha mendengar lagi Maha Mengetahui". ${ }^{5}$

Dari ayat-ayat tersebut menunjukkan bahwa Allah menjamin rezeki tiap-tiap umatnya yang bekerja dijalan-Nya, bahkan dari sesuatu yang tidak pernah terpikir sekalipun.

Produktivitas, secara terminologi sangat erat kaitannya bekerja. Jadi, bisa simpulkan bahwa produktivitas dalam Islam, khususnya yang dibahas didalam Al-qur'an merupakan sesuatu konsep yang sangat penting. Adapun ayat - ayat yang membahas mengenai produktivitas yaitu firman Allah dalam Al-qur'an Q.S An-Nisa' ayat 95

Terjemahnya:

"Tidaklah sama antara orang beriman yang duduk (yang tidak turut berperang) tanpa mempunyai uzur (halangan) dengan harta dan jiwanya. Allah melebihkan derajat orang - orang yang berjihad dengan harta dan jiwanya atas orang-orang yang duduk (tidak ikut berperang tanpa halangan). Kepada masing - masing, Allah menjanjikan (pahala) yang baik (surga) dan Allah melebihkan orang-orang yang berjihad atas orang yang duduk dengan pahala yang besar". ${ }^{6}$

Kata kunci dari ayat diatas, terkait produktivitas adalah kata "berjihad". Akan tetapi, ayat tersebut harus dipahami secara konseptual bukan secara kontekstual. Seandainya kita memahami ayat tersebut secara kontekstual, kata "berjihad" dalam ayat tersebut cenderung dekat dengan kata "berperang", atau dengan kata lain bahwa jihad itu diartikan perang secara fisik. Akan berbeda seandainya kita memahami ayat tersebut secara konseptual karena kata "berjihad" dalam ayat tersebut akan mempunyai makna yang lebih luas dan mendalam. Secara konseptual, kata "berjihad" dalam ayat tersebut dapat diartikan "bekerja".

\footnotetext{
5 Departemen Agama Republik Indonesia, Al-Qur'an ..., h. 404

${ }^{6}$ Departemen Agama Republik Indonesia, Al-Qur'an ..., h. 136
} 
Makna bekerja disini bukan dalam arti bekerja saat terjadi peperangan, tetapi bekerja dalam arti yang sangat luas, sebagai contoh misalnya; bekerja untuk mencari nafkah bagi keluarga.

Dengan catatan, bahwa proses bekerja yang dilakukan diridhoi oleh Allah SWT (halal hukumnya). Islam melarang menyia-nyiakan apapun bahkan menuntut untuk memanfaatkan apa saja menjadi sesuatu yang lebih baik. firman Allah dalam Al- Qur'an Surat Al-Asr 1-2 :

Terjemah :

"Demi masa. Sesungguhnya manusia itu benar-benar dalam kerugian". ${ }^{9}$

Inilah ayat yang menggambarkan bahwa sangat penting untuk memanfaatkan sumber daya yang telah dianugerahkan Allah SWT. Dari input yang berupa waktu akan terlihat tingkat produktivitas seseorang, ada yang waktu tersebut hanya terbuang sia-sia tanpa menghasilkan sesuatu peningkatan apapun, namun ada juga orang yang memanfaatkan waktu dengan sangat baik sehingga terlihat adanya peningkatan demi peningkatan dari segi ibadahnya, pekerjaannya, perilakunya, amal salehnya, dan lain-lain.

Kelayakan produktivitas tercermin pada besarnya produksi, kualitas produk, efektivitas dan efesiensi serta realisasi kepuasan para pekerja pada tingkat maksimal. Karena itu, sebaiknya masyarakat diarahkan pada perkembangan kepribadian yang produktif sehingga kelayakan produksi dapat tercapai. ${ }^{7}$

Kelayakan produksi sangat tergantung pada profesionalisme kerja individu. Professionalisme tidak tergantung hanya pada keahlian dan keterampilan kerja individu atau situasi kerja yang kondusif tetapi juga pada fakor-faktor psikis. Misalnya, minat individu terhadap pekerjaan dan rasa terlibat dengan profesi dan lembaga. Hal itu tergantung pada pemahaman indiviu terhadap nilai kerja, urgensi dan peranannya dalam produksi dan

${ }^{7}$ Abdul Hamid Mursi, SDM yang Produktif Pendekatan Al-Quran dan Sains, (Jakarta : Gema Insani Press, 1997), h. 44 
hubungannya dengan strategi umum produksi. ${ }^{8}$ Dalam Islam sebagaimana firman Allah dalam Al-qur'an surat Fushilat 41: 33

Terjemah:

"Siapakah yang lebih baik perkataannya daripada orang yang menyeru kepada Allah, mengerjakan amal yang saleh, dan berkata: "sesungguhnya aku termasuk orang-orang yang menyerah diri?".9

Amal pekerjaan pada ayat ini dan ayat lainnya, meliputi amal keagamaan yakni melaksanakan amal syariah dan amal lainnya, terutama pekerjaan indusrtial. Balasan bagi amal yang baik juga meliputi materi dalam kehidupan di dunia, meskipun balasan itu dimaksud sebagai petunjuk terhadap balasan materi didunia, Allah SWT berfirman dalam Al-Qur'an surat Yunus $10: 61$

Terjemah :

"Kamu tidak berada dalam suatu keadaan dan tidak membaca suatu ayat dari Al Quran dan kamu tidak mengerjakan suatu pekerjaan, melainkan Kami menjadi saksi atasmu di waktu kamu melakukannya. tidak luput dari pengetahuan Tuhanmu biarpun sebesar zarrah (atom) di bumi ataupun di langit. tidak ada yang lebih kecil dan tidak (pula) yang lebih besar dari itu, melainkan (semua tercatat) dalam kitab yang nyata (Lauh Mahfuzh)"10

Ayat diatas menjelaskan bahwa apapun yang kita kerjakan di dunia sudah tercatat dalam kitabnya. Sehingga pentingnya penghayatan terhadap makna-makna yang terkadung dalam al-Quran. Dengan penghayatan tersebut diharapkan tumbuh sikap yang konsekuen dalam prilaku yang selalu megarah pada cara kerja yang efesien dan memanfaatkan waktu dengan sebaik-baiknya dalam bekerja. Sikap seperti ini merupakan modal dasar yang selalu berorientasi pada nilai-nilai produktif. Firman Allah dalam Al-Qur'an surat al-Kahfi $18: 7$

Terjemah :

"Sesungguhnya kami Telah menjadikan apa yang di bumi sebagai

8 Ibid, h. 55

${ }^{9}$ Departemen Agama Republik Indonesia, Al-Qur'an ..., h. 778

10 Departemen Agama Republik Indonesia, Al-Qur'an ..., h. 316 
perhiasan baginya, agar kami menguji mereka siapakah di antara mereka yang terbaik perbuatannya ". ${ }^{11}$

Ayat diatas menjelaskan bahwa hamparan bumi dengan segala isinya agar manusia berusaha secara produktif mengelolanya untuk kemaslahatan dan sumber penghidupan bagi manusia. ${ }^{12}$ Setiap orang berhak atas segala hasil usahanya seperti disebutkan pada firman Allah dalam Al-Qur'an surat An-N isaa (4) : 32 yaitu:

Terjemahnya :

Dan janganlah kamu iri hati terhadap apa yang dikaruniakan Allah kepada sebahagian kamu lebih banyak dari sebahagian yang lain. (karena) bagi orang laki-laki ada bahagian dari pada apa yang mereka usahakan, dan bagi para wanita (pun) ada bahagian dari apa yang mereka usahakan, dan mohonlah kepada Allah sebagian dari karuniaNya. Sesungguhnya Allah Maha mengetahui segala sesuatu. ${ }^{13}$

Ayat diatas menjelaskan bahwa setiap orang berhak atas segala hasil usahanya yang berdasarkan prinsip-prinsip ekonomi Islam. Karena itu setiap pelaku ekonomi harus mematuhi prinsi-prinsip dasar Islam tentang ajaran sosial ekonomi, seperti jujur dan adil dalam berbuat, berucap, dan bersikap terhadap orang lain. Perekonomian masyarakat yang didasari dengan kejujuran dan keadilan akan menjadi maju dan berkembang serta dapat mewujudkan kemakmuran masyarakat.

\section{Prinsip Bekerja Menurut Islam}

Menurut Syamsudin, seseorang pekerja atau pengusaha muslim dalam melakukan berbagai aktivitas usaha harus selalu bersandar dan berpegang teguh pada prinsip berikut:

1. Seorang muslim harus bekerja dengan niat yang ikhlas karena Allah SWT. Karena dalam kacamata syariat, bekerja hanyalah untuk menegakan ibadah kepada Allah SWT agar terhindar dari hal-hal yang

\footnotetext{
${ }^{11}$ Departemen Agama Republik Indonesia, Al-Qur'an ..., h. 444

${ }^{12}$ Rusdi, M. A. (2017). Maslahat Sebagai Metode Ijtihad Dan Tujuan Utama Hukum Islam. DIKTUM: Jurnal Syariah dan Hukum, 15(2), 151-168.

${ }^{13}$ Departemen Agama Republik Indonesia, Al-Qur'an ..., h. 122
} 
diharamkan dan dalam rangka memelihara dari sifatsifat yang tidak baik, seperti meminta-minta atau menjadi beban orang lain.

2. Seorang muslim dalam usaha berhias diri dengan akhlak mulia, seperti: sikap jujur, amanah, menepati janji, memunaikan hutang dan membayar hutang dengan baik, memberi kelonggaran orang yang sedang mengalami kesulitan membayar hutang, menghindari sikap menangguhkan pembayaran hutang, tamak, menipu, kolusi, melakukan pungli (pungutan liar), menyuap dan memanipulasi atau sejenisnya.

3. Seorang muslim harus bekerja dalam hal-hal yang baik dan usaha yang halal. Sehingga dalam pandangan seseorang pekerja dan pengusaha muslim, tidak akan sama antara proyek dunia dan proyek akhirat. Baginya tidak akan sama antara yang halal dan haram. Ia akan selalu menghalalkan yang halal dan mengharamkan yang haram, bahkan hanya sebatas yang dibolehkan oleh Allah SWT dan Rasul-Nya. Seorang muslim dalam bekerja harus menunaikan hak-hak yang ditunaikan, baik yang terkait dengan hak-hak Allah SWT atau yang terkait dengan hak-hak manusia. Karena menunda pembayaran hutang bagi orang yang mampu merupakan suatu kedzaliman. Menyia-nyiakan amanah dan melanggar perjanjian bukanlah akhlak seorang muslim, hal itu merupakan kebiasaan orang-orang munafik.

4. Seorang muslim harus terhindar dari transaksi riba atau berbagai bentuk usaha haram lainnya yang menggiring ke arahnya. Karena dosa riba sangat berat dan harta riba tidak berkah, bahkan hanya akan mendatangkan kutukan dari Allah SWT dan Rasul-Nya, baik di dunia maupun akhirat.

5. Seorang muslim tidak boleh memakan harta orang lain dengan cara haram dan batil, karena kehormatan harta seseorang seperti kehormatan darahnya. Harta seorang muslim haram untuk diambil kecuali dengan kerelaan hatinya dan sebab syar'i untuk mengambilnya, 
seperti upah kerja, laba usaha, jual beli, hibah, warisan, dan yang semisalnya.

6. Seorang pekerja atau pengusaha muslim harus menghindari segala bentuk sikap maupun tindakan yang bisa merugikan orang lain. Ia juga harus bisa menjadi mitra yang handal sekaligus competitor yang bermoral yang selalu mengedepankan kaidah "Segala bahaya dan yang membahayakan adalah haram hukumnya".

7. Seorang pekerja atau pengusaha muslim harus berpegang teguh pada aturan syari'at dan bimbingan Islam agar terhindar dari pelanggaran dan penyimpangan yang mendatangkan saksi hukum dan cacat moral.

8. Seorang muslim dalam bekerja dan berusaha harus bersikap loyal kepada kaum mukminin dan menjadikan ukhuwah diatas kepentingan bisnis, sehingga bisnis tidak menjadi sarana untuk menciptakan ketegangan dan permusuhan sesama kaum muslimin. Dan ketika berbisnis jangan berbicara sosial, sementara ketika bersosial jangan berbicara bisnis, karena berakibat munculnya sikap tidak ikhlas dalam beramal dan berinfak.

Prinsip bekerja dalam Islam juga dijelaskan oleh Akh. Muwafik Saleh dalam bukunya yang berjudul Bekerja dengan Hati Nurani, mengatakan selama ini, banyak orang bekerja untuk mengajar materi belaka demi kepentingan duniawi, mereka tak sedikitpun memerdulikan kepentingan akhirat kelak. Oleh karena itu sudah saatnya para pekerja bekerja dengan motivasi yang dapat memberikan kepribadian yang baik dan dibenarkan oleh Islam yang harus memenuhi ciri-ciri sebagai berikut ${ }^{14}$ :

1. Niat Baik dan Benar (Mengharap Ridha Allah SWT)

Sebelum seseorang bekerja, harus mengetahui apa niat dan motivasi dalam bekerja, niat inilah yang akan menentukan arah pekerjaan. Jika niat bekerja hanya untuk mendapatkan gaji, maka hanya itulah yang

${ }^{14}$ Akh. Muwafik Saleh, Bekerja dengan Hati Nurani, (Erlangga, 2009), h. 65 
akan didapat. Tetapi jika niat bekerja sekaligus untuk menambah simpanan akhirat, mendapat harta halal, serta menafkahi keluarga, tentu akan mendapatkan sebagaimana yang diniatkan. Rasulullah SAW bersabda:

Dari Sa"ad bin Abu Waqqash radiallahu 'anhu, Rasulullah Shallallahu "Alaihi wa Sallam bersabda kepadanya: "Sesungguhnya apa saja yang kamu nafkahkan (bekerja) yang kamu niatkan untuk mencari keridhaan Allah niscaya kamu akan diberi pahala sebagai apa yang kamu sediakan untuk makan istrimu." (HR. Bukhari-Muslim). ${ }^{15}$

2. Takwa Dalam Bekerja

Takwa di sini terdapat dua pengertian. Pertama, taat melaksanakan perintah dan menjauhi segala bentuk larangan-Nya. Kedua, sikap tanggung jawab seorang muslim terhadap keimanan yang telah diyakini dan diikrarkannya. Orang yang bertakwa dalam bekerja adalah orang yang mampu bertanggung jawab terhadap segala tugas yang diamanahkan. Orang yang bertakwa atau bertanggung jawab akan selalu menampilkan sikap-sikap positif, untuk itu orang yang bertakwa dalam bekerja akan menampilkan sikap-sikap sebagai berikut:

a. Bekerja dengan cara terbaik sebagai wujud tanggung jawab terhadap kerja dan tugas yang diamanahkan.

b. Menjauhi segala bentuk kemungkaran untuk dirinya dan orang lain dalam bekerja. Misalnya, tidak malas-malasan, merugikan rekan kerja, dsb.

c. Taat pada aturan.

Hanya menginginkan hasil pekerjaan yang baik dan halal. Allah SWT menjamin balasan kepada orang-orang yang bertaqwa dalam kehidupan ini, termasuk dalam bekerja. Firman Allah SWT dalam QS. At-Talaq/65:2 disebutkan:

Terjemah:

“Apabila mereka telah mendekati akhir iddahnya, Maka rujukilah

${ }^{15}$ Akh. Muwafik Saleh, Bekerja..., h. 69 
mereka dengan baik atau lepaskanlah mereka dengan baik dan persaksikanlah dengan dua orang saksi yang adil di antara kamu dan hendaklah kamu tegakkan kesaksian itu karena Allah. Demikianlah diberi pengajaran dengan itu orang yang beriman kepada Allah dan hari akhirat. Barangsiapa bertakwa kepada Allah niscaya Dia akan Mengadakan baginya jalan keluar. ${ }^{16}$

3. Ikhlas Dalam Bekerja

Ikhlas adalah syarat kunci diterimanya amal perbuatan manusia disisi Allah SWT. Suatu kegiatan atau aktivitas termasuk kerja jika dilakukan dengan keikhlasan maka akan mendatangkan rahmat dari Allah SWT. Adapun ciri-ciri orang yang bekerja dengan Ikhlas yaitu:

a. Bekerja semata-mata mengharap ridha Allah SWT.

b. Bersih dari segala maksud pamrih dan ria.

c. Penuh semangat dalam mengerjakan seluruh tugas pekerjaan.

d. Tidak merasa rendah karena makian atau cercaan sehingga tidak mengurangi semangat dalam bekerja.

Allah SWT berfirman dalam QS. Ali-Imran/3:29 disebutkan :

Terjemah:

"Katakanlah: "Jika kamu Menyembunyikan apa yang ada dalam hatimu atau kamu melahirkannya, pasti Allah Mengetahui". Allah mengetahui apa-apa yang ada di langit dan apa-apa yang ada di bumi. dan Allah Maha Kuasa atas segala sesuatu". ${ }^{17}$

Mencari rezeki yang halal dalam agama Islam hukumnya wajib. Ini menandakan bagaimana penting mencari rezeki yang halal. Dengan demikian, motivasi kerja dalam Islam bukan hanya memenuhi nafkah semata tetapi sebagai kewajiban ibadah fardlu lainnya. Islam sangat layak untuk dipilih sebagai jalan hidup (way of life). Islam tidak hanya berbicara tentang moralitas akhlak, tetapi juga memberikan peletakan dasar tentang konsep-konsep membangun kehidupan dan peradaban tinggi.

Islam menganjurkan umatnya agar memilih aktivitas dan karir yang benar-benar selaras dengan kecenderungan dan bakatnya. Dengan

\footnotetext{
16Depertemen Agama Republik Indonesia, Al-Qur'an ..., h. 559

17 Depertemen Agama Republik Indonesia, Al-Qur'an ..., h. 54
} 
demikian, Islam meletakkan dasar yang kuat akan kebebasan berusaha. Hanya saja, untuk menghindari gejala-gejala kejahatan, Islam meletakkan batasan-batasan. Tujuan itu dinyatakan dalam Al-Qur'an dengan ungkapan bahwa bekerja adalah ibadah.

Menurut syari'at, keridhaan Allah SWT tidak akan didapatkan jika kita tidak melaksanakan tugas tekun, sungguh-sungguh dan sempurna. Ambisi seorang mukmin dalam bekerja yang paling utama adalah mendapatkan ridha Allah SWT. Dari ambisi yang mulia ini timbul sikap jujur, giat dan tekun. ${ }^{18}$

Firman Allah SWT QS. At-Taubah/9:105 disebutkan :

Terjemahnya:

"Dan Katakanlah: "Bekerjalah kamu, Maka Allah dan Rasul-Nya serta orang-orang mukmin akan melihat pekerjaanmu itu, dan kamu akan dikembalikan kepada (Allah) yang mengetahui akan yang ghaib dan yang nyata, lalu diberitakan-Nya kepada kamu apa yang telah kamu kerjakan. ${ }^{19}$

Ayat di atas memerintahkan agar kita bekerja, kerja itulah yang akan dilihat Allah SWT sebagaimana disebutkan dalam ayat tersebut tidak selalu bahwa yang satu dianugerahi derajat lebih tinggi dari yang lain, tetapi dimaksudkan bahwa kelebihan itu tidak lain daripada kelebihan keahlian dalam bidang kerja masing-masing. ${ }^{20}$

Dengan demikian, setiap orang pasti mempunyai kelebihan atas orang lain dalam bidang kerja tertentu dan dengan adanya kelebihan inilah setiap orang memerlukan bantuan orang lain untuk dapat terselenggaranya kebutuhan-kebutuhan hidupnya.

18 Yusuf Qardhawi, Norma Dan Etika Ekonomi Islam, alih bahasa Zainal Arifin dan Dahlia Husin, (Jakarta : Gema Insani Press, 1997), h. 115

${ }^{19}$ Depertemen Agama Republik Indonesia, Al-Qur'an ..., h. 204

20 Ahmad Azhar Basyir, Garis Besar Sistem Ekoonomi Islam, (Yogyakarta: BPFE, 1987), h. 26. 


\section{Sumber dan Faktor Produktivitas Kerja}

Untuk mengukur produktivitas kerja, diperlukan suatu indikator, ${ }^{21}$ sebagai berikut :

1. Kemampuan

2. Meningkatkan hasil yang dicapai

3. Semangat kerja

4. Pengembangan diri

5. Mutu

6. Efesiensi

Manusia sebagai tenaga kerja untuk tetap produktif harus mampu mendayagunakan sumber tenaga kerja baik yang terdapat pada dirinya maupun lingkungan sekitarnya. Adapun sumber produktivitas yaitu :

1. Penggunaan pikiran

Produktivitas kerja dikatakan tinggi jika untuk memperoleh yang maksimal dipergunakan cara yang paling mudah dan tidak memerlukan banyak pikiran yang rumit dan sulit.

2. Penggunaan tenaga jasmani dan fisik

Produktivitas dikatakan tinggi apabila didalam mengerjakan sesautu diperoleh hasil yang jumlahnya terbanyak dan mutu terbaik tidak banyak digunakan tenaga jasmani dan mutu terbaik, tidak banyak dipergunakan tenaga jasmani dan fisik yang melelahkan, sebaliknya produktivitas dikatakan rendah apabila dikaitkan dengan banyak mempergunakan tenaga kerja jasmani/ fisik sedangkan hasilnya sedikit.

3. Penggunaan waktu

Produktivitas dari segi waktu berkenaan dengan cepat atau lambat pencapaian suatu hasil dalam kerja. Untuk mencapai hasil tertentu diperlukan waktu yang singkat ini berarti produktivtas kerja mengalami kenaikan yang tinggi.

${ }^{21}$ Edy Sutrisno, Manajemen Sumber Daya Manusia, ( Jakarta : Kencana, 2011), Edisi I, cet.ke-3, h.104-105 
4. Penggunaan ruang suatu pekerjaan.

Dikatakan produktif apabila ruang yang luas, sehingga tidak memerlukan mobilitas yang jauh pemakaian ruang yang luas akan memperpanjang jarak yang harus ditempuh tenaga dalam mewujudkan kerjasama dengan orang lain dalam melaksanakan suatu perkerjaan.

5. Penggunaan material/ bahan dan uang.

Dikatakan produktif apabila penggunaan material/ bahan baku dan peralatan tidak terlalu banyak yang terbuang dan harganya tidak terlalu mahal tanpa mengurangi hasil yang hendak dicapai.

Produktivitas yang tinggi akan dapat dicapai apabila faktor yang mempengaruhi produktivitas itu selalu dipenuhi. Untuk itu dibawah ini akan diberikan beberapa cara bagaimana meningkatkan semangat kerja baik yang bersifat material maupun non material, adapun cara untuk meningkatkan adalah sebagai berikut: 22

1. Gaji yang cukup.

Setiap perusahaan seharusnya dapat memberikan gaji yang cukup kepada karyawan, artinya jumlah gaji tersebut mampu dibayarkan oleh perusahaan tanpa menimbulkan kerugian bagi perusahaan dan dengan jumlah gaji yang diberikan tersebut diharapkan dapat meningkatkan produkrivitas kerja.

2. Memperhatikan kebutuhan rohani.

Kebutuhan rohani antara lain menyediakan tempat menjalankan ibadah, rekreasi, partisipasi dan lain sebagainya.

3. Sekali-kali perlu menciptakan suasana santai.

Dengan cara tidak membebankan karyawan pekerjaa-pekerjaan rutin pada saat tertentu dan memberikan konsumsi cuma-cuma dan bersama-sama menikmatinya.

4. Tempatkan karyawan pada posisi yang tepat.

22 Nitisemito Alex, Manajemen Personalia, (Jakarta : Ghalia Indonesia, 2000), h. 149 
Setiap perusahaan harus mampu menempatkan keryawan pada posisi yang tepat sesuai dengan keterampilan dan pendidikan yang dimiliki oleh karyawan tersebut

5. Berikan kesempatan kepada mereka untuk maju.

Hal ini menimbulkan semangat kerja baik bagi karyawan tersebut untuk itu perusahaan hedaknya memberikan kesempatan kapada setiap karyawan untk mengembalikan diri.

6. Perasaan aman menghadapi masa depan perlu diperhatikan.

Karena karyawan biasanya enggan terlalu detil menanyakan keadaannya dan status dirinya dipersuhaan kepada atasannya keran takut resiko akan dipecat/ diperlakukan berbeda dengan karyawan lain.

7. Pemberian insentif yang terarah.

Karena ini sangat efektif dan dalam mendorong semangat dan kegiatan kerja para karyawan.

\section{Penutup}

Produktivitas, secara terminologi sangat erat kaitannya bekerja. Jadi, bisa simpulkan bahwa produktivitas dalam Islam, khususnya yang dibahas didalam Al-qur'an merupakan sesuatu konsep yang sangat penting. Bekerja untuk mencari nafkah adalah hal yang istimewa dalam pandangan Islam. Allah telah berjanji kepada orang yang beriman dan melakukan pekerjaan yang baik bahwa bagi mereka ampunan Allah dan ganjaran yang besar.

Manusia sebagai tenaga kerja untuk tetap produktif harus mampu mendayagunakan sumber tenaga kerja baik yang terdapat pada dirinya maupun lingkungan sekitarnya. Untuk mengukur produktivitas kerja, diperlukan suatu indikator, sebagai berikut: Kemampuan, Meningkatkan Hsil yang dicapai, Semangat kerja, Pengembangan diri, Mutu, Efesiensi. 


\section{Daftar Pustaka}

Basyir, Ahmad Azhar, Garis Besar Sistem Ekonomi Islam, Yogyakarta: BPFE, 1987.

Depertemen Agama Republik Indonesia, Al-Quran dan Terjemah, Semarang : PT Karya Toha Putra, 2002

Knight Dunlap, Personal Adjustment, New York: Alexander Hamilton Institute, 1990

Kuncoro, Mudrajat, Metode Riset untuk Bisnis dan Ekonomi Edisi 3, Jakarta: Penerbit Erlangga, 2009.

Kreitner, Robert dan Angelo Kinicki, Perilaku Organisasi, alih bahasa Erly Suandy, Jakarta: Reksohadiprojo,

Mangkunegara A. Anwar, Manajemen Sumber Daya Manusia Perusahaan, Bandung: PT Rosda

M. Kadarisman, Manajemen Pengembangan Sumber Daya manusia, Jakarta: Raja Grafindo Persada, 2012.

Qardhawi, Yusuf, Norma Dan Etika Ekonomi Islam, alih bahasa Zainal Arifindan Dahlia Husin, Jakarta :Gema Insani Press, 1997.

Rivai, Veithzal. Manajemen Sumber Daya Manusia Untuk Perusahaan, Jakarta: PT. Raja Grafindo Persada, 2010

Rusdi, M. A. (2017). Maslahat Sebagai Metode Iitihad Dan Tujuan Utama Hukum Islam. DIKTUM: Jurnal Syariah dan Hukum, 15(2), 151-168.

Shaleh, Akh. Muwafik, Bekerja dengan Hati Nurani, Erlangga, 2009.

Sinungan, Muchdarsyah, Produktivitas Apa dan Bagaimana, Jakarta: Bumi Aksara, 2003.

Suprihanto, John, Manajemen Personalia, Yogyakarta: Penerbit BPFE, 1987. 